\title{
The South African Transition: From Development to Security?
}

\section{Steffen Jensen}

\begin{abstract}
This article questions some recent analyses which claim that global neo-liberal discourses are disseminated to shift the focus away from development towards a greater emphasis on security issues. Taking as its point of departure the analysis of empirical material from Cape Town, the article shows that security and development in South Africa were never separate concerns. After the ANC came to power in 1994 there was an effort to boost development efforts rather than security. However, these efforts were soon dwarfed by local circumstances, notably the pressure from local state employees who felt their jobs and lives to be under threat from the townships, and the changing nature of violence in the city. The first part of the article details the practices and discourses of state agencies; the second section analyses the consequences of reconfigured security and development concerns for the production of political subjectivity in South Africa's townships.
\end{abstract}

\section{INTRODUCTION}

Academia has been paying increasing attention to the concept of 'security' in recent years, and not only in the field of political science (for example, Bauman, 1997; Beck, 1992; Comaroff and Comaroff, 2001; Duffield, 2001; Hettne, 2001). This reflects a coalescence of social trends in which 'security' has become an issue of everyday individual and collective experiences of fear and violence, as well as a new discourse occupying a central place on international and national political agendas. In South Africa, security has assumed political centrality, and violence and crime appear to fundamentally threaten the fragile transition to democracy. The preoccupation with security undoubtedly relates to extremely high levels of violence. However, since 1994 the incidence of crime has remained more or less stable, albeit at an

The research for this article has been made possible by grants from the Danish Council for Development Research and the Danish Research Council for the Social Sciences. Lars Buur, Simon Turner, Peter Gibbon, Finn Stepputat and Henrik Rønsbo all commented on earlier versions of the paper. Finally the anonymous referees provided important inputs in the final phases of writing the article.

Development and Change 36(3): 551-570 (2005). (C) Institute of Social Studies 2005. Published by Blackwell Publishing, 9600 Garsington Road, Oxford OX4 2DQ, UK and 350 Main St., Malden, MA 02148, USA 
unacceptably high level: ${ }^{1}$ complementary explanations must therefore be sought for the growing dominance of the security discourse. This applies not only in South Africa, but also on a global scale.

In their attempts to explain the increased focus on security, several commentators point to the emergence of neo-liberal global trends. Duffield (2001), for instance, locates the rise of security in the disappearance of the bipolar world. Whereas violence and conflict were previously seen as indicators of social transformation in many Third World countries, today's policy-makers and observers view violence as an indicator of danger, social dysfunction and anomie. This means, Duffield argues, that inequality is no longer sufficient reason for conflict but something from which the wealthy part of the world must protect itself through increased surveillance and security interventions (ibid.: 7). Even more to the point, Wacquant (1999) argues that a neo-liberal orthodoxy on security has been disseminated from American think-tanks to the rest of the world. This neo-liberal orthodoxy is 'aiming to criminalize poverty — and thereby to normalize precarious wage labour'. It has been 'incubated in America, [and] is being internationalized [...] in the realm of "Justice" (Wacquant, 1999: 321, emphasis in original). This has, he argues, led to the proliferation of terms such as 'war on drugs', 'war on crime' and 'zero tolerance' across the globe from New York to Cape Town (ibid.: 329). This discursive shift has, according to Duffield (2001) and Wacquant (1999), profound implications in the areas and among the groups subjected to criminalization in terms of democratic inclusion and the ability to sustain livelihoods.

The analyses of travelling security concerns appear to have merit. However, they tend to be somewhat reductionist in their statements, and they tend to ignore or downplay the ways in which these global discourses are appropriated in particular contexts. A first point of argument in this article, then, is that historically security and development were always merged in South Africa. A further point is that, although security discourses in the second half of the 1990s seemed to become more prominent, what took place was a reconfiguration of the relationship between security and development rather than a univocal shift. A third contention is that, rather than being effected through the global dissemination of a neo-liberal orthodoxy, the reconfiguration was the result of distinct processes within the local state and discursive shifts within the local public sphere. Finally, the

1. Although official crime statistics are often unreliable, and crime and violence underreported, they do indicate trends (for elaboration, see Institute for Security Studies, 1998). Most observers agree that only when it comes to murder are statistics relatively accurate. According to Interpol statistics, in the period between 1994 and 2001 there has been a small decline in the number of murders from approximately 60 murders for every 100,000 people to under 50 per 100,000 in 2001. Although this makes South Africa one of the most violent countries in the world, there is no radical upward change (see www.interpol.int/public/statistics/ICS/downloadlist.asp). 
reconfiguration of development and security has consequences beyond the state in which they are affected, as the parameters for the production of political subjectivities shift.

Before moving on, some clarification is needed regarding the terms 'development' and 'security'. Both concepts have been enmeshed in intense academic and political debate that I will not attempt to summarize here. ${ }^{2}$ Suffice it to say that by juxtaposing the concepts, Duffield (2001) and Wacquant (1999) assume that we can identify two distinctly different spheres. Development in their version is associated with the extension of services like water, education, welfare and the like, which are aimed at bettering the lives of indigent populations, whereas security is associated with physical safety and containment of danger. For Duffield (2001) and Wacquant (1999), development is clearly the better option, as development aims at helping 'them' and security aims at securing 'us'. Apart from the normative stance these commentators adopt, there is also a need to disaggregate the concepts along at least two distinct lines. First, for township people in South Africa and elsewhere, security and development are inherently merged, since a good life is seen as the absence of insecurity and the presence of development. Second - and here the distinction between security and development does make sense - policies that focus primarily on security tend to be different, and more excluding, than policies focusing on development. Within this second sense, which forms the focal point of the article, we need to analyse how the policies are played out, and often intertwine, in diverse political power struggles for allocation of resources, entitlements and identity claims.

Although its empirical focus is on Cape Town's coloured ${ }^{3}$ townships, the aim of the article is broader, as I trace processes that happen elsewhere in South Africa and abroad. However, the Cape townships are paradigmatic in that they present the problematique in acute form: the coloured townships have emerged as singularly violent places, with widespread vigilante retribution and criminal (often gang-related) activity, and development as well as security interventions have proliferated over the decades. The article begins by examining the creation of coloured townships during the apartheid regime, and demonstrates that security concerns always worked alongside socio-economic or developmental concerns. It then moves on to examine the effects of post-apartheid governmentality. Through an examination of everyday discourses and practices of lower level state bureaucrats within the Cape Town City Council (henceforth 'the Council') and of how these

2. For elaboration on the concept of development, see for instance Crush (1995); Escobar (1995); Ferguson (1990); Long (2001). For security, see for instance Smith and Bayliss (1997); Stern (2001); Wæver (1997).

3. The coloureds emerged as a racial category inscribed in law alongside Africans, Indians and whites with the passing of the Population Registration Act of 1950. For elaboration, see Goldin (1989); Jensen (2001); Western (1996). 
merged with broader, public discourses of crime in Cape Town, I trace the reconfiguration of development and security at this particular historical juncture. As Seekings (1996) has argued, the period after 1994 was characterized by a weakening of civil society organizations. Until new social movements - organizing around electricity, water, AIDS and privatization, for example - emerged after $2000,{ }^{4}$ most civic groups were organized around crime fighting. After analysing the reconfiguration within the state, I turn to the townships and explore how state practices and discourses emanating from the reconfiguration impact on township residents' room for political manoeuvring. The argument is that the focus on crime changes the scope for political mobilization compared to development issues like water, electricity and health problems, as crime tends to move the enemy of the community inside itself and even into the family.

\section{THE CREATION OF COLOURED TOWNSHIPS: SECURITY AND DEVELOPMENT}

Apartheid governance has always been intensely preoccupied with security issues, and at least partially structured by the need to secure the state and the white polity from invading natives or non-whites. As Pinnock (1989) argues, from around the turn of the last century Cape Town became a 'garrison city'. City planning, most clearly with the introduction of the Group Areas Act and the forced removals from the 1950s, became essentially a question of separating the different race groups formalized under the Population Registration Act. The coloureds, as an intermediate group between whites and Africans, occupied a particular position within the racial hierarchy as a 'buffer' between the two main groups, as whites were not as fearful of them as of Africans. This position also informed city planning and invariably coloured group areas would be positioned between whites and Africans. Security concerns also informed more minute city planning. As Pinnock (1984) and Western (1996) argue, townships were constructed with very few exit roads to render them easier to cordon off, should the need arise. These brief remarks point to the apartheid regime's constant preoccupation with security. But apartheid was about more than strict security and inter-racial relations. Development concerns were always integral to state interventions. To see this we need to take a closer look at apartheid governmentality towards the coloureds, who constituted a different kind of security problem than Africans.

4. These organizations do not organize around crime but around everyday development issues. Interestingly for the argument on security, several of the organizations claim, with differing legitimacy, to have been criminalized by the state. 
Governmental objectification of and interventions into the coloured group were informed by two impulses: they drew inspiration from interventions towards poor whites (Badroodien, 2000) and evolved around notions of a specific coloured criminality (Jensen, 2000, 2001). Of these I concentrate on the latter. From the early part of the twentieth century, several commissions of inquiry (such as the Wilcocks Commission of 1937, the Liquor Commission of 1945 and the Theron Commission of 1976) pointed to the ever-present threat of coloured men becoming criminals. This stereotypical abstraction of a man prone to drink, lazy, good-for-nothing but happy-go-lucky and always on the verge of becoming a criminal - incarnated in the figure of the kaapse skollie (see, for instance, the Liquor Commission, 1945: 6) - came to inform much of the apartheid regime's dealings with regard to the coloureds. Nowhere was this more obvious than in the Department of Coloured Affairs (DCA). It was charged with carrying out the policies of separate development - that is, each racial group should be governed differently according to their cultures - in relation to coloureds. Although the DCA often became the ideological smokescreen that legitimated apartheid's oppression of coloureds (as has been argued by activists and academics including Goldin, 1989; Lewis, 1987), it nonetheless had consequences for the way in which oppression was carried out. The DCA worked from the premise that a coloured middle class, guided by whites, should be charged with uplifting the coloured underclass (Division of Coloured Affairs, 1952). This was based on analyses of the commission reports, which concluded that three distinct class groups had emerged within the coloured group. The commissions distinguished between a small, relatively well-educated middle-class, a group of coloured men already riddled with decay and a large, undecided group of labourers and farm workers who might go either way. DCA interventions were primarily aimed at the latter group and the interventions were inherently gendered. Whereas women fought an uphill battle against the disintegration wrought by urbanization, men were seen as the direct cause of women's struggle to be home-makers, as the DCA put it in various Annual Reports (for example, Department of Coloured Affairs, 1975: 7, 26; House of Representatives, 1991: 6).

Interventions into the coloured underclass had their roots in the experiences the state gained in dealing with the poor whites, but they reflected this racialized, gendered and classed analysis. Women were assisted in numerous ways to become true home-makers: they were given courses and trained in housekeeping, and an elaborate welfare system was extended to them (Jensen, 2001: 79-81). Men, on the other hand, were locked up or sent to industrial schools (Badroodien, 2000) and work camps from an early age. At a time when South Africa had the highest incarceration rate in the world, coloured men were four times more likely to go to prison than African men, even though coloureds were not affected by the pass laws that put many Africans behind bars (Pinnock, 1984: 74). Apartheid was a system of repressive welfarism that began with the poor whites, but was increasingly extended to coloureds and Indians (Badroodien, 2000). 
What transpires from these brief remarks is that development concerns, or the bio-political interventions aimed at developing the coloured body politic, were always intimately linked to criminality and security. ${ }^{5}$ South Africa was far from being alone in this. Barry Hindess (2001) asserts that liberal government - a category to which the different versions of South African governance would belong - works from the premise that the less governments interfere in the lives of people, the better it is, but on any given territory there are people who 'are not endowed with a capacity for autonomous action' (ibid.: 100), and who must be dealt with through what Hindess calls 'liberal unfreedom'. He identifies three responses from government to this incapacity for autonomy: extermination, authoritarian intervention and welfare intervention (ibid.: 101). I focus on the latter two. The authoritarian response, holding that the capacity for freedom can only be fostered through compulsion and extended periods of disciplining, is notably applied to colonized populations, the unemployed and the deviant (ibid.: 103-6). The welfare response has been applied to those who suffered setbacks and needed help to get by and attain the capacity for freedom. Governmental interventions oscillate between the different modes of intervention. ${ }^{6}$ As a group, coloureds were contained and isolated for security reasons, coloured men were clearly subjected to forms of authoritarian governmentality, and poor women were subjected to compulsion and discipline as well as to welfare interventions to render them capable of taking care of the family. Hence, forms of development always appeared to be intertwined with security concerns. If this is the case, how might we argue that a shift from development to security has occurred in the 1990s? Have development and security not always been merged? To explore these issues, we need to follow the trail of post-apartheid governmentality in and around Cape Town. As we shall see, what happens in Cape Town is less a question of easily identifiable shifts and more about a reconfiguration of the relationship between security and development concerns.

\section{POST-APARTHEID GOVERNMENTALITY: DEVELOPMENTAL LOCAL GOVERNMENT}

As the ANC took over government in 1994, the party and local state representatives knew that their hold on the townships, African as well as

5. This process was not confined to the coloured community. Africans were also objects of the merging of security and development concerns, albeit in completely different ways. For elaboration, see for example Mamdani (1996); Moodie (1995); Ross (2001); Sparks (1990).

6. It is clearly difficult to equate all South African governments, from the segregationist period before the Second World War, over apartheid to the post-apartheid era, and that is not my purpose. However, Hindess points to structures that were similar, although they were played out in radically different ways and with very different means of oppression. 
coloured, was, at best, tenuous. Large-scale consumer boycotts along with rent and service payment boycotts had been introduced at the end of the 1980s as an integral part of the struggle, but they prevailed after 1994. The late 1980s were dominated by intense, often violent, township riots where large sections of many townships became no-go zones into which the state might venture only in armoured vehicles. While the unrest was particularly intense in African townships, coloured townships also had their share (Seekings, 2000), especially centred on secondary schools. According to the ANC government, there were two interrelated reasons for the 'ungovernability': extremely unequal financial resource distribution and increased mobilization against the apartheid regime's institutions of local government. In order to bring the townships back under state control, a new contract between the people of the townships and the state was needed in which the former would be approached differently. Local government was to have a crucial role in this recuperation, but 'a fundamental transformation [ . . was] required' (Republic of South Africa, 1998: section A5). For this transformation to take place, the priorities of local government had to change fundamentally from sustaining the former order towards what is called 'developmental local government': 'Developmental local government is local government committed to working with citizens and groups within the community to find sustainable ways to meet their social, economic and material needs and improve the quality of their lives' (ibid.: section $\mathrm{B} 1$ ).

To a large extent, this new approach to local government was inspired by the Reconstruction and Development Programme (RDP), which became the ANC's 1994 election platform. The RDP was to become one of the most important strategies to re-introduce development as the key to rehabilitating the ungovernable townships. It featured five key aims of developmental government: meeting basic needs; developing human resources; building the economy; democratizing state and society; and finally developing strategies that would see the other aims implemented (ANC, 1994: 1).

In order to begin working along the lines of developmental local government, after the first democratic local government elections in 1996 the Cape Town City Council drew up a set of strategic priorities for the city. The seven priorities were the following: a framework for integrating the city; equity and redistribution; targeting poverty and social disintegration; housing and homelessness; economic development and job creation; promoting community safety; and a range of special projects aimed at realizing the priorities (City of Cape Town, 1999). In relation to the violence-torn and poverty-stricken Cape Flats the priority to target zones of poverty and social disintegration proved to be of perennial importance. In the 1998-9 manual for development of business plans, zones had to be identified in order to 'create an enabling environment and to restore/build formal governance in them'. In terms of recuperating the city, these were the areas that had to be targeted. The Council writes about these 'zones': 
Certain parts of the city suffer from extremes of poverty and/or social disintegration. Some of these areas are reasonably well serviced, while others are not. Each branch is requested to provide information and assist in developing indicators, which will help to identify which areas should be selected for priority action (whether this is short-term crisis intervention or longer term action). Indicators could include lack of basic services, high incidence of violence and gang activity, severe health problems, high rates of rape and violence against women and children. (City of Cape Town, 1997: 12)

What emanates from this list is that although the areas are zones for development intervention, they are defined and identified through criteria that speak as much of security (high incidence of violence, gang activity and rape) as of development (basic services, health problems), with no mention of employment or economy. Hence, although the Council formulates its strategies according to ideas of developmental government, security plays a prominent role in its adaptation of national strategies.

Why and how did this reconfiguration take place? I argue that we need to look at two separate developments that coalesced in the mid-1990s: frontline state representatives' highly negative experiences of the townships as places that threatened their personal lives and rendered their work impossible; and public perceptions, inside and outside the townships, that crime in Cape Town had reached emergency levels, leading to an upsurge in collective action against criminals. I begin by exploring the fears and anxieties of front-line state representatives before moving on to the public discourses of crime.

\section{Securing the State}

The everyday experience of local state representatives was that the townships encroached upon the state and made it impossible for them to do their job. They told of gang-members who followed their enemies into the clinics to finish them off; of drugs being sold from council houses and violent rows when housing authorities intervened; and of how social welfare officials were attacked when they investigated cases of welfare fraud. In few other places was this sense of urgency and decay more acute than in the schools. ${ }^{7}$

Education and the teaching profession have always been important within the coloured population group and in the townships. Teachers came to constitute the backbone of the emerging coloured middle class; but it was also from the schools that the resistance against apartheid first took root,

7. The fieldwork on which this article is based was conducted between 1998 and 1999. It included interviewing teachers in secondary schools, being present during lectures and taking lectures as a substitute teacher, conducting focus group interviews with pupils, attending parent-school meetings and meetings between teachers, and being present during workdays and at celebrations. Fieldwork was also conducted in other state institutions such as the welfare office, the housing authorities and the clinics. All these frontline state representatives were preoccupied with separating township from state (see Jensen, 2001: 149-70). 
and schools became the loci of township insurgency during the 1980s in the coloured areas. The school in which I conducted fieldwork in 1998 and 1999 was no exception. Academically as well as politically, the school excelled in the 1980s, organizing extra-mural activities and becoming a hub for political mobilization. By 1998 and 1999, most of these activities had stopped. The school was severely affected by the reconfiguration in government spending on education towards African areas, and the pupil-teacher ratio had risen. Only twenty-two of the original fifty-two teachers remained, and of the 700 students, only 450 remained because those parents who could afford it sent their children to former white schools. This drain of better-off children left the school struggling financially as well as academically. Many other schools were in similar situations. This meant that teachers' overall work environment deteriorated. A senior teacher who had been at the school during the 1980s lamented the disappearance of the well-resourced students, while describing the children left in the school as follows:

Most of them come from single-parent homes where they are looked after by an older sister or a grandma because mommy has to go to work. A lot of them have to work when they come home. [ . . . Often they can't cope. Also, there is no backup from the parents. They don't take responsibility for anything. They want the school to teach the children values. But that is hopeless without support from the home and the parents. (Fieldwork interview)

Such sentiments were often underlined by issues of criminality and gangsterism. Several times during my fieldwork in the school, teachers would shout to misbehaving boys: 'Stop acting like a gangster, or you will end up in prison'. The misbehaving child was thus associated with the encroaching township beyond the school gates, where boys were gang-members. Inside the school gates, boys were pupils but one never knew what they did on the outside. In order to be able to teach at all, it was imperative that the township was kept outside the gates. Pointing to the barbed wire outside his window, the principal once remarked: 'Look, we have to live like in a prison'. Teachers always had to take cognisance of the area they were in. As one of them told me: 'Once we had a casual day, you know where the children could wear their own clothes to school. We will never do that again because the gangsters came to the school and messed everything up. And we couldn't see who was a gangster and who was not. Somebody got stabbed there in the school'.

That day, the fine line separating the school from the township brokedown. But the separation was perceived to be permanently compromised, and teachers explained that a reason for not doing extra-mural activities was that they were afraid to stay at school after hours, 'Because then the gangsters will come looking to see if there is anybody left'. During the time of my fieldwork, intimidation of teachers, vandalism and gangsterism at schools in the Western Cape had become a hot political issue. The Provincial Education Department had, as a pilot project, introduced electrified fences around one particularly affected school in Manenberg. This project was 
taken up by other schools, and in my fieldwork school both parents and teachers endorsed and supported the fence as a protection against vandalism and against marauding gang-members haunting the school. The person responsible for the idea of the fences explained that they were part of an initiative called Safer Schools: 'If we have a room that is pitch dark and we light one light in the furthest end of the room, the darkness will no longer be total. Then the first light will inspire another light and it again will inspire other lights' (interview with Zunade Dharsey, Safer Schools Project, Department of Education). At the time of the interview, he said there were no lights. Hence, in order to stabilize the schools, make them sources of light, fences were needed: 'The fence is a short-term solution for sure but something had to be done. It was like stabilizing the community through that one light - from the school. Sometimes people would look into the classes and abuse the teachers or beat up kids' (ibid.).

While the fences would offer very real and material signs of the separation of school and township, this separation cannot always be maintained with such certainty. The real problem lies with the boys who straddle the divide between 'us' (the orderly school) and 'them' (the chaotic township). These are the schoolboys who belong to gangs already and consequently bring the township with them (the strangers within), or other gang-members who come to the school to seek out their enemies among the pupils, as happened with the stabbing of the boy on 'casual day'. It is the boys who might turn to gangsterism, and if the school is to function, it is imperative that these tendencies are kept at bay.

However, due to poverty, social marginalization, inadequate resources and an acute sense of decay, the boundaries of the state (the clinic gates, the school fences, the guards outside the housing office) are sometimes compromised. In most encounters local representatives were convinced that coloureds in the townships were indeed caught in 'cultures of violence', 'cultures of entitlement' and 'cultures of dependency'. Rather than blaming apartheid, they saw township residents as somehow to blame for the inability of the state to work properly. Working in the 'zones of poverty and social disintegration' became a matter of surviving each day. Nowhere was this more pronounced than in Manenberg. Clinic staff refused to work after shootings; gangsters, fully armed, demonstrated outside the Rent Office; fences were built around schools; citizens and residents staged placard demonstrations outside the Rent office. In one incident the office was invaded by residents who took the housing manager hostage. Events like these prompted the Council to form the Manenberg Task Team in 1998. It was 'mandated by EXCO [Council's executive committee] to follow a course that ensures 1) staff safety and security, 2) staff receive maximum emotional and psychological support, 3) that plans to ensure service delivery be put in place, 4) that there be clear communication mechanisms for staff, the public and the media, and 5) that we link this to a long-term strategy' (City of Cape Town, 1998: 4). 
The project aimed at minimizing the risks to Council staff and teaching the Council as a whole to engage with 'dysfunctional communities' through security measures: 'hardening the premises including identifying safe rooms; area co-ordination including bleepers and panic buttons; transport of staff in and out of the area; risk management; identification of role players for long term strategies, and emotional and psychological support'. All this had to be done in order 'to bring service levels back to what may be considered normal' (ibid.: 5-6). Most of the project tasks centred on security and equipping staff members to handle township residents and users of Council services.

Manenberg was a special case where the prevalence of gangs, poverty, crime and overcrowding went hand in hand with a civil society sharply opposed to state agencies. Council staff recognized the particularity of Manenberg as a violent space, but during my fieldwork there was consistent generalization about township areas. Although areas had different positions on a hierarchy from very disintegrated and/or poor to less so, they were lumped together under the collective term of 'zones of poverty and social disintegration'. Although Manenberg is special, it became the quintessential 'zone' and the looming fate of all township areas.

This was brought home to me in an interview with a housing manager who returned from a visit to Charlotte in Georgia, USA, as part of a City to City project. $^{8}$ She told me:

It was quite an eye-opener to me. They [the Charlotte authorities] have created a city within a city. That could be for instance the Cape Flats within the greater metropole. Then they have graded the areas in what they term fragile, threatened and stable areas. So the job is to keep threatened areas out of the category of the fragile and slowly turn them into stable ones. As it is now, most of the Cape Flats is fragile and these areas hold the city to ransom. It is people from there that go and rob and commit violence. In council terms it is 'zones of poverty'. (Fieldwork interview)

These zones of poverty and social disintegration are seen as threatening not only for state agents but for the entire Cape Town social fabric. Interestingly, the three categories of fragile, threatened and stable, and the way they are employed, resemble the urban counter-insurgency tactics of the apartheid regime's 'Total Strategy' (Sparks, 1990: 354-8; see also McCuen, 1966: 196-206, 324-30). This division underlines the assertion that security became the lens through which the Council viewed the townships, so that, increasingly, the Council adopted security measures - guards, panic buttons, fences and police protection - in its 'war on poverty'.

8. The City to City project was an exchange programme between cities in the Third and First World where the cities should learn from each other. As part of the programme, a group of local government officials and NGO-personnel from Cape Town went to Charlotte, Georgia. 


\section{The Public Discourses of Crime and the Rise of Collective Action}

From around 1996, the idea that, before developmental local government can be undertaken, it is necessary to secure the ability of the state to function, coalesced with an increased public focus on crime, which had taken hold inside and outside the townships and among rich and poor. Crime and violence had always been everyday issues in the townships but they did not figure centrally within ANC discourse before 1996. Crime, along with other day-to-day issues like housing and welfare, was subsumed under the greater narrative of the anti-apartheid struggle. When gangs looted trucks coming into the townships during the 1980s, activists saw and applauded it as part of the struggle. But by 1996, local concerns with crime, fuelled by gang wars tearing families and neighbourhoods apart, entered national politics with a vengeance. Mid-1996 saw the emergence in Cape Town of the Muslim vigilante-type organization Pagad, ${ }^{9}$ after the killing of a notorious drug dealer by an angry mob made national headlines. During the latter part of 1996 and in the beginning of 1997, mass demonstrations against renowned drug dealers, shootings, executions and attacks on police stations and the judiciary compelled state agencies to react. The Minister of Justice at the time, Dullah Omar, asserted in the week following the killing of the drug dealer that although he vehemently opposed citizens taking the law into their own hands, 'The organization has wakened the soul of the community. The tragedy [...] can have good results. I am not saying that you have to kill people to have good results, but now the authorities are sitting up, listening and planning. We should use the atmosphere that has been created to good effect' (Dullah Omar, quoted in Manjra, 1996: 39).

The initial successes caused a groundswell of support in the general population, if not for Pagad then at least for collective, extra-state action (Idasa, 1998). This is not the place for a detailed examination of Pagad and collective violence (for this, see Jensen, 2001, forthcoming); suffice to say that although Pagad lost virtually all public support, the organization left an indelible mark on both local and national politics. It initiated a particular modus operandi that was to change the nature of violence in Cape Town; at the same time, crime became a top priority on the national political agenda and one of the tests that the new democratic state had to pass to secure votes and gain support from the 'new' citizens in the townships and the city at large.

The reconfiguration towards increased security was by no means unequivocal or straightforward: there were dissenting and influential voices promoting

9. Pagad (or the People Against Gangsterism and Drugs) was formed in 1995 on the Cape Flats and comprised largely middle-class Muslims. For elaboration, see Dixon and Johns (2001); Jensen (2001, forthcoming); Manjra (1996). 
development and democratization issues inside government. It was rather a gradual process or tendency which characterized the latter part of the 1990s. It is illustrated, for example, by a policy shift in ANC discourse from the first election period — when Sydney Mufamadi and Dullah Omar, both stalwarts of the civic movements in the 1980s, were made ministers of Safety and Security and Justice respectively - to the second, when the Safety and Security portfolio was given to Steve Tshwete, a former ANC military commander in exile. As a wave of violence hit Cape Town in September 1997, Dullah Omar explained it by pointing to unreformed elements within the security forces and police who allegedly released prisoners 'at night to perpetrate violence against specific targets before returning to jail' (Mail and Guardian, 30 September 1997). Hence, crime and violence were explained through recycling struggle narratives in which those faithful to the apartheid regime did their utmost to destroy the new South Africa. By contrast, after another spate of violence three years later, Steve Tshwete called for police powers to be increased to include the right to use lethal force: 'Criminals must know that the South African Police possesses the authority, moral and political, to ensure by all means, constitutional or unconstitutional, that the people of this country are not deprived of their human rights' (Mail and Guardian, 10 November 2000). The police were given support and new legislative and institutional powers to deal with the tide of crime. In the process of assigning this greater emphasis to security, the visions of developmental local government discourse seemed to have been subsumed and reconfigured as security concerns. Townships were no longer just the unfortunate victims of apartheid that needed to be redeemed through development initiatives, but also the very cause for the failure of the state to work properly for the democratization and development of South Africa as a whole. As a consequence, in public discourse and within the state, new measures were needed - tough laws, special police units and calling in the military to patrol the townships.

\section{From Development to Security, Revisited}

In the light of this reconfiguration, can we argue that the discourses of development were merely an interlude before the focus on security and the stereotypes of the dangerous black male took over once again? Hein Marais (1998) argues that the ANC never truly embraced radical democratic ideas - rather, it based its politics on bourgeois nationalist politics just as the previous regime had done. Hence when the socialist-democratic RDP strategy was replaced by the neo-liberal economic strategy of Growth, Equity and Redistribution (GEAR) in 1996, it was only showing its true colours. Marais (ibid.: 146-76) illustrates how easy it was for local capitalist interests, aided by neo-liberally inclined international financial institutions 
and consultants, to turn the economic policies of South Africa towards neoliberalism.

It is certainly true that the South African government introduced neoliberal policies; it focused more intensely on security, and it invited a number of foreign security experts to South Africa as consultants. The 'father' of Zero Tolerance, the former New York Chief of Police William Bratton, came to South Africa on a number of occasions. However, Marais' analysis seems to provide only a partial picture. First, for every neo-liberal American police officer entering South Africa, there were dissenting voices and opposing experts. For every William Bratton there was a Clifford Shearing - a highly influential Canadian criminologist, promoting community policing and radical police reform linked to socio-economic reform (Brogden and Shearing, 1993). Second, although neo-liberal policies were introduced and fiscal discipline became important, South Africa's move to neo-liberal orthodoxy was not unequivocal. The country spends more on welfare, education and health now than ever before. The welfare state has not in fact been rolled back: rather, fiscal and state resources have been reprioritized and deracialized to cater for Africans.

Ironically, this reprioritization has impacted most heavily on the coloured population. Welfare grants, once paid almost exclusively to coloured women, have been replaced by a much smaller, universal, child support grant. In public education, the teacher-student ratio has come down in African areas but increased in coloured township schools. The health care system is being revamped and clinics in the coloured areas now also cater for Africans. Despite claims to developmental local government, the practical effects of resource allocation have thus been a reduction of developmental initiatives in coloured townships. However, this was framed within the notion of 'addressing the inequalities of the past' and not necessarily within globally disseminated, neo-liberal discourses of 'rolling back the state'.

It thus seems that the intertwining of security and development in state discourse and practice have undergone a reconfiguration rather than a shift. The evidence presented here suggests the importance of looking beyond the neo-liberal argument, and of taking local histories and processes into account. In the case study, factors including pressure from local state representatives, their experiences of the townships as threatening, and the changing patterns and perceptions of public violence in Cape Town, played a role in the reconfiguration of development and security.

\section{SECURITIZATION AND POLITICAL SUBJECTIVITIES ON THE CAPE FLATS}

What are the implications of rising concerns about security for the production of political subjectivities in the township? To answer this question we should first consider the concept of securitization. In an important 
contribution to the debate on securitization within political science, ${ }^{10}$ Ole Wæver argues that neither security nor states - nor, for that matter, other actors - are unproblematic entities of analysis. Who is identified as a threat depends on the power relations in a given context. Security then becomes a 'speech act' where 'the word "security" is the act; the utterance is the primary reality' (Wæver, 1997: 222). Wæver goes on to assert that what characterizes an issue that has become securitized is that it becomes a matter of survival: "By saying "security" a state-representative moves the particular case into a specific area; claiming a special right to use the means necessary to block this development. "Security" is the move that takes politics beyond the established [democratic] rules of the game, and frames the issue within a special kind of politics' (ibid.: 14). Posing the concept of security in these terms means that security is no longer necessarily lodged within particular institutions but has become a practice that we might analyse ethnographically.

Following Wæver, the measures adopted to protect state representatives on the Cape Flats, and the national discourse promoted by Tshwete, securitized politics and moved it into a domain where survival (of the state and the nation) was at stake. What is needed, according to Wæver, is that those promoting securitization are able to name a particular situation as an emergency that needs special intervention. However, Wæver's analysis tells us little about what happens to those who embody the security problem, or how they are able to engage in autonomous political action. In this regard, the work of Giorgio Agamben (1998, 2000) adds important dimensions to the analysis. Agamben follows Carl Schmidt, who asserts that sovereignty is defined by the ability to name particular situations as extreme emergencies in which the normal rule of law might be discounted (Schmidt, 1922/1985: 5). When Tshwete asserts that the South African state has the moral and political legitimacy to deal with criminals constitutionally or unconstitutionally (Mail and Guardian, 10 November 2000), he is, in Schmidt's framework, expressing something integral to sovereignty.

Agamben's (1998) concept of sovereignty is paired with another figure outside the rule of law — what he calls Homo Sacer, or 'naked life'. These two figures exist in a mutually dependent relationship outside the normal political game, as Wæver would put it, where sovereignty is constituted through the ability to name somebody as the embodiment of the extreme emergency - or Homo Sacer — whose death cannot be ritualized, nor can those killing them be prosecuted (ibid.: 82). These are Tshwete's criminals, who have 'relegated their own status to that of sub-humans' (Mail and Guardian, 10 November 2000). However, the embodiments of the extreme emergency are not defined only by their criminal acts: they are the

10. Security is a hotly-debated concept within political science. For elaboration and critique, see Smith and Bayliss (1997) and Stern (2001). 
racialized, classed, aged and gendered objects that in Cape Town are a group of young, coloured men from townships. Through the racialized stereotypes, coloureds in townships are all affected by this securitization.

So what are the implications of securitization for political mobilization, or the constitution of political subjectivities, on the Cape Flats? Following Wæver, crime (as a security issue) involves a different kind of politics than development issues like water, electricity, land or health, which after 2000 have been successfully politicized. This seems to be true in the Cape example: residents involved in local politics or community work attempted, in different ways, to resist the state's description of the townships as dangerous. Although they are intensely aware of how damaging the violence and the gangs are, and, like other residents, have to cope with violence in everyday life (see Jensen, 1999), they do not concur with the image portrayed by state officials of the townships. They protest against teachers branding township children as trouble-makers; when a clinic was closed down, they argued that 'it was only "mad Rafie" who had come into the clinic and caused the problem; they ridicule welfare officials who are afraid to check for welfare fraud; and they sneer at police for cowardice when they come to crime scenes in armoured vehicles.

While the danger may be exaggerated, there is very little that community workers can do to counter the fears of state representatives. The differences in appreciation of danger speak of a conceptual gap between state and residents in their approach to security and development. For residents, security concerns are part of lived experiences of particular events, places and persons, and solving the problems of crime relates intimately to socioeconomic reform of state and society. The state's description of 'zones of poverty and social disintegration' as the source of danger affects and impacts on community workers' scope for action in several ways. We might tentatively identify three different sets of consequences for the production of political subjectivity.

First, as the state became increasingly preoccupied with crime and violence, many interventions were aimed at eradicating violence. New bodies such as the Community Policing Forum or the Safer Schools project were formed, and community workers were invited to participate in them. These bodies emerged in a time when civic life was in a slump and activists were uncertain of their role in the new South Africa (Seekings, 1996). In the context of a general decline in state presence in the first years after 1994, crime and violence became the most important point of encounter between the state and the community workers. Although community workers insisted that there were pressing problems apart from crime and violence, they had little choice but to accept the problematization of the Council which prioritized crime, since the state controlled resource allocation and the policy process (see Jensen, 2004). Although not necessarily agreeing with the state, community workers picked up the challenge, as they needed to engage with the state to uphold political legitimacy. The rules of the game in 
the political field were determined by the state - and those rules were informed by security rather than development concerns, at least until 2000 when, for instance, the Treatment Action Committee (TAC) successfully politicized health and AIDS issues.

Secondly, and paradoxically, community workers needed to reinforce the state's appreciation of townships as problematic. They needed the townships to be seen as poor and socially disintegrated, in order both to access funds for the township and to secure themselves a position from which they could help township residents. If their particular townships were not included in the 'zone of poverty' category, the flow of money would stop, and their privileged position as community workers - between the poor and innocent people of the township and the state agencies — would be compromised.

Finally, the categorization of certain townships as 'dysfunctional communities', and the increased focus on crime, impacts on community workers in one more way. During the struggle against apartheid and in the years immediately following 1994, the enemy or threat was generally seen to emanate from outside the community. The problems besetting the townships internal violence, poverty, gangs, disintegration of families, informal and often illicit economic activities from drug peddling to welfare scams, incarcerated men - were all attributed to the regime. However, the discursive shift within the state towards security meant that the enemies of the community were located within the township itself. Instead of engaging politically with the repressive state, community work became a matter of fighting crime and violence within the township. This is the crucial political impact when crime takes centre-stage over development issues. Whereas new social movements such as the Treatment Action Committee, the Landless People's Movement and the Anti-Privatization Forum can identify threats outside their own group (usually in an uncaring, neo-liberal state), a politics which focuses on crime tends to locate the enemy within the community, even within the family. This makes it infinitely more difficult to claim moral innocence, but it also radicalizes the paradoxes which community workers face. As I have argued elsewhere (Jensen, 2004), many of the power struggles between community workers revolve around issues of crime and violence. Some are charged with having too close a relationship with gangs; others have family members dealing in drugs, serving terms in prison or participating in gangs. Others are affiliated to vigilante groups and are accused of bringing raids and other unwelcome forms of police presence to the township. When townships - through governmental objectification and intervention and township politics - become epicentres of danger rather than the unfortunate victims of apartheid or post-apartheid governance, the difficulties of communities and community workers are exacerbated. Of course, this not only affects Cape Town, but holds true wherever and whenever crime becomes an important element in the dominant description of particular places (see, for example Glaser, 2000). 


\section{CONCLUSION}

This article has examined the ways in which security came to impact on governance in Cape Town after 1994. I have argued that security and development had always been intertwined in Cape Town and that the reconfiguration which took place during the 1990s had as much to do with local specificities as with global neo-liberal trends, as some commentators have argued. Specifically, I identified the pressure on the new democratic state, preoccupied with political legitimacy, from a concerned city populace and from its own front-line employees, to put more emphasis on crime and violence. I also explored what consequences this reconfiguration might have on political mobilization and the production of political subjectivity. Crime as an issue involves a different kind of politics than, for instance, water and health, even if community organizations are given a hand in the fight against crime. Although the attempt by the ANC government to involve communities in this way was presumably aimed at returning the city to its people and democratizing government through community participation, the ways in which community was conceptualized, employed and fought over in Cape Town in fact resulted in marginalizing the townships once again. This time, however, the enemies are located within the townships, and there is no readily identifiable outside enemy. This is one of the great ironies of post-apartheid local politics in Cape Town - that the reconfiguration of security and development has reproduced marginalization. Securitization has, potentially at least, left the coloured part of the Cape Flats at war with itself, as community workers - having assumed the role of patrollers and informers - fight family, friends and neighbours in the name of greater security for all. The reconfiguration of development and security and its influence on state practices and discourses, has thus impacted significantly on the room for political action within the townships.

\section{REFERENCES}

Agamben, G. (1998) Homo Sacer: Sovereignty and Bare Life. Stanford, CA: Stanford University Press.

Agamben, G. (2000) Means Without End: Notes on Politics. Minneapolis, MN, and London: University of Minnesota Press.

ANC (1994) 'A Basic Guide to the Reconstruction and Development Programme.' Available online: www.anc.org.za/ancdocs/policy/short.htm

Badroodien, A. (2000) 'A History of the Ottery School of Industries in Cape Town: Issues of Race, Welfare and Social Order in the Period 1937 to 1968.' PhD dissertation. University of Western Cape.

Bauman, Z. (1997) Postmodernity and its Discontents. London: Polity Press.

Beck, U. (1992) Risk Society: Towards a New Modernity. London: Sage.

Brogden, M and C. Shearing (1993) Policing for a New South Africa. New York: Routledge.

City of Cape Town (1997) 'Manual for the Drafting of the 1998 Business Plan'. Cape Town.

City of Cape Town (1998) 'Manenberg Task Team: Project Definition Report'. Cape Town. 
City of Cape Town (1999) 'Strategic Priorities'. Cape Town.

Comaroff, J. and J. Comaroff (2001) Millennial Capitalism and the Culture of Neo-Liberalism. Durham, NC: Duke University Press.

Crush, J. (1995) The Power of Development. London: Routledge.

Department of Coloured Affairs (1975) 'Annual Report' (DCA). Pretoria: Government Printer.

Division of Coloured Affairs (1952) 'Annual Report'. Pretoria: Government Printer.

Dixon, B. and L. Johns (2001) 'Gangs, Pagad and the State: Vigilantism and Revenge Violence in the Western Cape'. Violence and Transition Series, vol. 2. Johannesburg: Centre for the Study of Violence and Reconciliation.

Duffield, M. (2001) Global Governance and the New Wars: The Merging of Development and Security. London: Zed Books.

Escobar, A (1995) Encountering Development: The Making and Unmaking of the Third World. Princeton, NJ: Princeton University Press.

Ferguson, J. (1990) The Anti-Politics Machine: 'Development', Depoliticization and Bureaucratic Power in Lesotho. Minneapolis, MN: University of Minnesota Press.

Glaser, C. (2000) 'Bo-Tsotsi': The Youth Gangs of Soweto, 1935-1976. Cape Town: David Philips.

Goldin, I. (1989) Making Race: The Politics and Economics of Coloured Identity in South Africa. London: Addison-Wesley.

Hettne, B. (2001) Comparing Regionalisms: Implications for Global Development. Basingtoke: Palgrave.

Hindess, B. (2001) 'The Liberal Government of Unfreedom', Alternatives 26(2): 93-111.

House of Representatives (1991) 'Annual Report' (DCA). Pretoria: Government Printer.

Idasa (1998) 'Crime and Community Action on the Cape Flats 1996-97'. Public Opinion Survey No 4. Cape Town: Institute for a Democratic Alternative in South Africa.

Institute for Security Studies (1998) Crime in Cape Town: Results of a City Victim Survey. Monograph series No 23. Pretoria: Institute for Security Studies.

Jensen, S. (1999) 'Discourses of Violence: Coping with Violence on the Cape Flats', Social Dynamics 25(2): 75-97.

Jensen, S. (2000) 'Of Drug Dealers and Street Gangsters: Power, Mobility and Violence on the Cape Flats', Focaal 36: 105-16.

Jensen, S. (2001) 'Claiming Community, Negotiating Crime: State Formation, Neighborhood and Gangs in a Capetonian Township'. PhD Dissertation, Roskilde University.

Jensen, S. (2004) 'Claiming Community: Local Politics on the Cape Flats, South Africa', Critical Anthropology 24(2): 179-207.

Jensen, S. (forthcoming) 'Above the Law: Practices of Sovereignty in Surrey Estate, Cape Town', in Thomas Hansen and Finn Stepputat (eds) Sovereign Bodies. Princeton, NJ: Princeton University Press.

Lewis, G. (1987) Between the Wire and the Wall: A History of South African 'Coloured' Politics. Cape Town: David Philips.

Liquor Commission (1945) 'Report of the Cape Coloured Liquor Commission of Inquiry'. Pretoria: Union of South Africa. Government Printer.

Long, N (2001) Development Sociology: Actor Perspectives. London: Routledge.

Mail and Guardian (1997) 'Third Force on the Cape Flats' (30 September) Johannesburg.

Mail and Guardian (2000) 'Tshwete gets Tough on Crime' (10 November) Johannesburg.

Mamdani, M. (1996) Citizen and Subject: Contemporary Africa and the Legacy of Late Colonialsm. Princeton, NJ: Princeton University Press.

Manjra, S. (1996) 'Battle Plans in the Pagad Struggle: Political Fascism vs. Democracy', in R. Galant and F. Gamieldien (eds) Drugs, Gangs and People's Power: Exploring the Pagad Phenomenon, pp. 37-44. Cape Town: Claremont Main Road Masjid.

Marais, H. (1998) South Africa - Limits to Change: The Political Economy of Transformation. London: Zed Books.

McCuen, J. (1966) The Art of Counter-Revolutionary War. London: Faber and Faber. 
Moodie, D. (1995) Going for Gold: Men, Mines and Migration. Berkeley, CA: University of California Press.

Pinnock, D. (1984) The Brotherhoods: Street Gangs and State Control in Cape Town. Cape Town: David Philips.

Pinnock, D. (1989) 'Ideology and Urban Planning: Blueprints of a Garrison City', in W. James and M. Simons (eds) The Angry Divide, pp. 150-68. Cape Town: David Philips.

Republic of South Africa (1998) 'White Paper on Local Government'. Ministry of Local Government. Pretoria: Government Printer.

Ross, R. (2001) A Concise History of South Africa. Cambridge: Cambridge University Press.

Schmitt, C. (1922/1985) Political Theology: Four Chapters on the Concept of Sovereignty. Cambridge: MIT Press.

Seekings, J. (1996) 'The Decline of South Africa's Civic Organizations, 1990-1996', Critical Sociology 22(3): 135-57.

Seekings, J. (2000) The UDF: A History of the United Democratic Front in South Africa, 1983-1991. Oxford: James Currey.

Smith, S. and J. Bayliss (1997) The Globalization of World Politics: An Introduction to International Relations. Oxford: Oxford University Press.

Sparks, A. (1990) The Mind of South Africa. London: William Heineman.

Stern, M. (2001) 'Naming In/Security: Constructing Identity: Mayan Women in Guatemala on the Eve of "Peace"'. PhD Dissertation, Göteborg University.

Theron Commission (1976) 'Commission of Inquiry into Matters relating to the Coloured Group'. Pretoria: Republic of South Africa Government Printer.

Wacquant, L. (1999) 'How Penal Common Sense Comes to Europeans: Notes on the Transatlantic Diffusion of the Neoliberal "Doxa", European Societies 1(3): 319-52.

Western, J. (1996) Outcast Cape Town. Berkeley, CA: University of California Press.

Wilcocks Commission (1937) 'Commission of Inquiry regarding Cape Coloured Population of the Union'. UG 54 - 1937. Pretoria: Union of South Africa. Government Printer.

Wæver, O. (1997) 'Conceptualizing Security’. PhD Dissertation, University of Copenhagen.

Steffen Jensen works at Roskilde University, PO Box 260, DK-4000 Roskilde, Denmark (steffenj@ruc.dk) and is a fellow at Wiser in Johannesburg. He has published on gangs, policing, local politics and vigilantism, while his current research interests revolve around justice and the production of gendered and generational power in rural South Africa. 